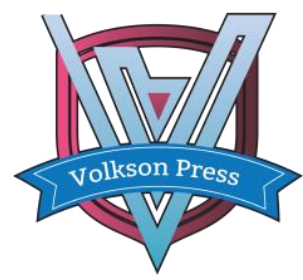

Contents List available at VOLKSON PRESS

Economics \& Management Innovations(EMI)

DOI : http://doi.org/10.26480/icemi.01.2017.232.234

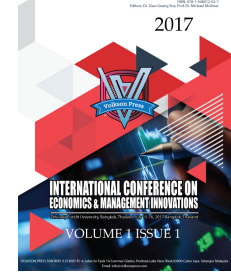

\title{
The Impact of Aesthetic Value on Economic Value in Clothing Fashion Show
}

\section{Yang Xiugang Lyu Tianxiang}

110/1-4 Prachachuen Road, Tungsonghong, Laksi, China-Asean International College of Dhurakji Pundit University, Bankok, Thailand. Email: lyangxg@126.com; 419133783@qq.com

This is an open access article distributed under the Creative Commons Attribution License, which permits unrestricted use, distribution, and reproduction in any medium, provided the original work is properly cited.

\section{ARTICLE DETAILS}

\section{Article History:}

Received 02 october 2017 Accepted 06 october 2017 Available online 11 october 2017

\section{Keywords:}

aesthetic value, fashion show,

economic value, substitution

effect, asynchrony.

\section{ABSTRACT}

due to lack of study on influence of aesthetic value in clothing fashion show on clothing economic value to customer, this research paper analyzes the data from questionnaire on base of relative literature and find that clothing aesthetic value significantly influence on the clothing economic value positively, yet the influence of stage performance on clothing economic value is negatively significant in clothing fashion show due to substitution effect between clothing aesthetic value and stage performance as they both influence on clothing economic value, the reason lies in asynchronous influence between clothing fashion show and clothing economic value.

\section{Introduction}

Regarded as the industry of the sun never set in runway, fashion show is an art form (Lise Skov, Else Skjold, Brian Moeran, Frederik Larsen and Fabian F. Csaba,2009). Fast fashion is a process for co-created value by textile businesses, providers, retailers, stores, customers those interacted within supply chain or value chain (Andrea Moretta Tartaglione\& Emanuela Antonucci,2013). A cloth in a fashion show posses the aesthetic value and economic value ascribes it is both an artwork and a product. By using a content expert with a process that combines conventional audio description techniques with colour commentary techniques to allow emotion and excitement as well as description of the important visual elements, a live fashion show is enjoyable and entertaining for blind, lowvision and sighted audiences(Udo, JP and Fels, Deborah I.,2009). So we get hypothesis 1 in fashion show to customers.

H1:the influence of stage performance on aesthetic value is significantly positive.

By economic psychology, impactful fashion marketing moderates the relationships among price and consumer demand for the firm's offering (i.e., brand) by psychological customer segments, and subsequently firm profitability (Arch G. Woodside,2012). For extending of this viewpoint, comes hypothesis 2 in context of clothing fashion show.

H2: stage performance significantly influence on clothing economic value positively.

Michael Hutter \& Richard Shusterman (2006) regarded some of the works of art created also have economic value when certain patterns of demand and supply are directly connected to some of the artistic values (i.e. Art's moral or religious value, cognitive value, communicative value, expressive value). Economic value increases when several varieties of artistic value are combined in a single work. The highest prices are attained for rare works or performances by most highly ranked masters that combine emotional impact with status and entertainment value. Thus, a final hypothesis for customers comes into being:

H3: clothing aesthetic value significantly influence on its economic value is positive.

Researches have well done in clothing fashion show in qualitative not quantitative, the way of measure are quite rough for clothing aesthetic value ,stage performance and clothing economic value, even the standard for their classification is not unified. With viewpoint of aesthetic marketing, this research pays not only attention to aesthetic value, but also clothing economic value in marketing meaning, different from common sense as usual, the measure of clothing economic value is from communicative willingness and purchase willingness in marketing aspects and viewpoint.

\section{The Providing of Research Framework}

Time and practice challenge the marketing theory, basing on the deficiency of literature, this paper gives research model as the structure functions showed bellow:

dressvalue $=\alpha_{0}+\alpha_{1}$ dressaethics $+\alpha_{2}$ stageperformance $+\delta_{1}$

dressaethics $=\phi_{0}+\phi_{1}$ line $+\phi_{2}$ style $+\phi_{3}$ matterial $+\phi_{4}$ color $+\phi_{5}$ picture $+\delta_{2}$

stageperformance $=\varphi_{1}$ stage $+\varphi_{2} \bmod e l+\varphi_{3}$ performance $+\delta_{3}$

dressvalue $=\beta_{0}+\beta_{1}$ communication $+\beta_{2}$ purchase $+\delta_{4}$

Here, dressvalue, dressaethics, stageperformance, line, style, material, color, picture, stage, model and performance respectively stand for clothing economic value, clothing aesthetic value, aesthetic value of stage performance in clothing fashion show, line on clothing, clothing style, clothing material, clothing color, picture on clothing, aesthetic value of stage, quality of model and aesthetic value of performance. In the structure functions, dressvalue, dressaethics and stageperformance are unobservable variables, and the line, style, material,color, picture in clothing as well as stage, model, performance, communication and purchase are observable variables.

3. The Measure of Variables, Questionnaire Design and Research Method

This paper obtains data through questionnaire at simple random by way of empirical study, samples including students for model schools, models in performance companies, stakeholders of clothing firms, designers for dressing, image makers, managers for model, teachers or scholars in colleges. 
For sake of max errors of sampling less than 0.05 in data, this paper issues 500 questionnaires and take back 450, 428 questionnaires are valid among them. The measure of variables, indicator system and questionnaire design are shown in table1.

By testing, both the degree of credibility and validness for questionnaire are accepted.(testing process omitted for saving space).

\section{Analysis for Data}

This paper research the influence of clothing aesthetic value, stage performance on clothing economic value, the model fit is summary in table2. Data shows model fits well. Path coefficients and matched data respectively show in figure 1 and table 3 .

From figure 1 we see that significant level of all the path coefficient are less than $1 \%$, that means clothing aesthetic value positively influence on the clothing economic value, clothing aesthetic value and stage performance positively influence with each other, and stage performance negatively influence on clothing economic value, they are all significant, the reason we explain respectively.

Table 1: Variables for Use

\begin{tabular}{|c|c|c|c|}
\hline variables & dimension & element & source \\
\hline \multirow{5}{*}{$\begin{array}{l}\text { dressaesthetics ( } \\
\text { X1) }\end{array}$} & Line(X11) & & \multirow{5}{*}{$\begin{array}{l}\text { J.P. Udo\&D. I. Fels(2010) } \\
\text { Wang Xinping (2015) }\end{array}$} \\
\hline & Style(X12) & & \\
\hline & Material(X13) & & \\
\hline & Color(X14) & & \\
\hline & Picture(X15) & & \\
\hline \multirow{8}{*}{$\begin{array}{l}\text { stageperformance } \\
\text { (X2) }\end{array}$} & \multirow{3}{*}{$\begin{array}{l}\text { Stage } \\
\text { (X21) }\end{array}$} & $\begin{array}{l}\text { Stage } \\
\text { layout(X211) }\end{array}$ & \multirow[t]{3}{*}{ Silberg\&Jon(2009). } \\
\hline & & Light effect(X212) & \\
\hline & & Music style(X213) & \\
\hline & \multirow{3}{*}{$\begin{array}{l}\text { Model } \\
\text { (X22) }\end{array}$} & Body(X221) & \multirow{3}{*}{$\begin{array}{l}\text { Jill Ross\& } \\
\text { Rod Harradine (2010). } \\
\text { Leng Detong (2009) }\end{array}$} \\
\hline & & Face(X222) & \\
\hline & & Posture(X223) & \\
\hline & \multirow{2}{*}{$\begin{array}{l}\text { Performance } \\
\text { (X23) }\end{array}$} & content(X231) & \multirow[t]{2}{*}{$\begin{array}{l}\text { MarjanMichels\&WilMeeus } \\
(2016)\end{array}$} \\
\hline & & $\operatorname{spot}(\mathrm{X} 232)$ & \\
\hline \multirow{5}{*}{$\begin{array}{l}\text { Dressvalue } \\
\text { (Y) }\end{array}$} & \multirow{3}{*}{$\begin{array}{l}\text { Communication } \\
\text { (Y1) }\end{array}$} & share(Y11) & \multirow{3}{*}{$\begin{array}{l}\text { Bristor (1991) } \\
\text { Antony\& Aumann(2014) }\end{array}$} \\
\hline & & Recommend(Y12) & \\
\hline & & Interaction(Y13) & \\
\hline & \multirow{2}{*}{ Purchase(Y2) } & Attitude(Y21) & \multirow[t]{2}{*}{ Meng Fei（2012） } \\
\hline & & Capacity(Y22) & \\
\hline
\end{tabular}

First, for positive influence of clothing aesthetic value on clothing economic value, when clothing aesthetic value is accepted by customers or satisfied dressers, they want to shift the beauty and fashion of models into their own bodies, the nature for seeking the beauty and fashion drives them to purchase that kind of clothing, even to share the happiness to own the clothes through the communication with others. This psychological process explain the significant positive relationship between clothing aesthetic value and it economic value.

Table 2: Model Fit Summary

\begin{tabular}{l|l|l|l|l|l|l}
\hline \multirow{2}{*}{ CMIN } & Model & NPA & CMIN & DF & P & $\begin{array}{l}\text { CMIN/D } \\
\text { F }\end{array}$ \\
\cline { 2 - 6 } & Default model & 22 & $\begin{array}{l}153.27 \\
3\end{array}$ & 33 & 0 & 4.645 \\
\hline \multirow{2}{*}{$\begin{array}{l}\text { RMR,GF } \\
\text { I }\end{array}$} & Model & RMR & GFI & AGFI & PGFI & \\
\cline { 2 - 6 } & Default model & 0.055 & 0.932 & 0.887 & 0.559 & \\
\multirow{2}{*}{ AIC } & Model & AIC & BCC & BIC & CAIC & \\
\cline { 2 - 6 } & Default model & 197.27 & $\begin{array}{l}198.43 \\
6\end{array}$ & $\begin{array}{l}286.57 \\
3\end{array}$ & $\begin{array}{l}308.57 \\
3\end{array}$ & \\
\hline
\end{tabular}

Second, the stage performance weakly influence on the clothing economic value by way of negative. The reason lies in four aspects: (1)When clothing economic value is comparatively low, clothing tradesmen are inclined to higher the value by clothing fashion show, but the customers or tradesmen do not accept that kind of marketing, while watching the clothing fashion show, they maybe give high revaluation for it, but that kind of revaluation is not high enough to achieve the degree to buy or recommend. Oppositely, when the clothing economic value is comparatively high, it is unnecessary to cause the willingness of customers to buy or communicate with others by marketing of clothing fashion show.(2) Preparing clothing fashion show inadequately, the content of clothing fashion show separated from its economic value, they are unmatched. Preferences and tastes of customers are different. Not all kinds of clothing fashion show are able to satisfy the aesthetic dement of any customers, that means clothing fashion show usually has none business of clothing economic value, neither higher price of clothes, nor lower that of them.(1)and(2) is called asynchronous. (3) When both clothing aesthetic value and stage performance variables are putted into the model, there is a substitution effect in influence of clothing aesthetic value and its stage performance on clothing economic value due to the interaction between clothing aesthetic value and stage performance, this makes the negative relationship linking stage performance and its economic value. When the aesthetic demand is not satisfied from market, the appropriate promotion of clothing fashion show will lead customers to find some beauty in clothes, causing the willingness of customers to purchase or recommend those clothes. This demonstrate the truth that stage performance is based on clothing aesthetic value, and stage performance is able to higher the aesthetic value for clothes.(4)Clothing fashion show is possibly show the beauty of model more than beauty of clothes, the sampling objects investigated pay more attention to the body, face , elegant step and graceful posture of models rather than the clothes themselves when they are watching the stage performance, this is in some degree to reduce the devotion of clothing fashion show to its economic value.

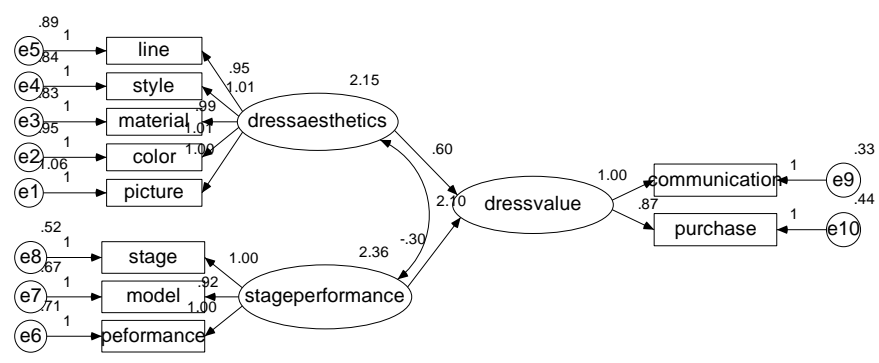

Figure 1: Path Coefficients Analysis

Final, the path coefficient links clothing aesthetic value and stage performance is 2.10 , means that clothing aesthetic value and clothing economic value help each other, at the time customers appreciate the stage performance, they care not only the result caused by clothing fashion show, but also the clothing aesthetic value especially in correlative clothing design circles. The clothing aesthetic value express and communicate through the stage performance, and clothing fashion show tells us how beautiful the clothes are, a great fashion show is able to meet the need of not only fashion show but also clothing aesthetics, they interact mutually. In summary, research hypothesis 1 has passed the testing, hypothesis 2 is failing to pass the testing, and research hypothesis3 has successfully to pass the testing, all the path coefficients are significant.

\section{Table 3: Regression Weight}

\begin{tabular}{|c|c|c|c|c|c|c|c|}
\hline & & & $\begin{array}{l}\text { Estimat } \\
\mathrm{e}\end{array}$ & S.E. & C.R. & $\mathrm{P}$ & $\begin{array}{l}\text { Labe } \\
1\end{array}$ \\
\hline dressvalue & $<--$ & dressaesthetics & .602 & .083 & 7.265 & *** & \\
\hline dressvalue & $<--$ & stageferformance & -.298 & .075 & -3.993 & *** & \\
\hline picture & $<---$ & dressaesthetics & 1.000 & & & & \\
\hline color & $<--$ & dressaesthetics & 1.008 & .049 & 20.679 & *** & \\
\hline material & $<--$ & dressaesthetics & .990 & .047 & 21.105 & *** & \\
\hline style & $<---$ & dressaesthetics & 1.007 & .047 & 21.211 & $* * *$ & \\
\hline line & $<--$ & dressaesthetics & .945 & .046 & 20.346 & *** & \\
\hline stage & $<---$ & $\begin{array}{l}\text { stageperformanc } \\
\mathrm{e}\end{array}$ & 1.000 & & & & \\
\hline model & $<---$ & $\begin{array}{l}\text { stageperformanc } \\
\text { e }\end{array}$ & .923 & .035 & 26.102 & $* * *$ & \\
\hline performance & $<--$ & $\begin{array}{l}\text { stageperformanc } \\
\text { e }\end{array}$ & .999 & .037 & 26.863 & $* * *$ & \\
\hline $\begin{array}{l}\text { communicatio } \\
\mathrm{n}\end{array}$ & $<---$ & dressvalue & 1.000 & & & & \\
\hline purchase & $<---$ & dressvalue & .872 & .092 & 9.495 & $* * *$ & \\
\hline dressaesthetics & $<-->$ & $\begin{array}{l}\text { stageperformanc } \\
\mathrm{e}\end{array}$ & 2.105 & .175 & 12.042 & $* * *$ & \\
\hline
\end{tabular}




\section{Conclusions and Suggestions}

This paper analyses have shown that clothing aesthetic value is positively influence on the clothing fashion show, clothing aesthetic value is positively influence on its economic value at the same time, yet the stage performance is negatively influence on clothing economic value weakly due to substitution effect and asynchrony, all path coefficients are all credible and significant. Based on the conclusion we give some managing suggestions bellow:

First, clothing manufacturers ought to enhance the product design under condition of guaranteeing the quality of products to meet the aesthetic needs increasing every day, especially adding the input in weak aspects like clothing colors and styles etc, keeping and enhancing the strong aspects like clothing pictures, lines and materials, clothing design should combine the comfort and fashion of clothes, tightly follow the tide of design, try to express the life quality and social status, for sake of attracting the interesting of customers, in favorite of self-realization for customers, getting win-win situation among customers and firms.

Second, clothing tradesmen ought to reasonably adopt the marketing way of clothing fashion show to increase the clothing economic value, to attract the eyeball of customers by choice of right music style, light effect, and stage arrangement, even the excellent models and performance places to move and touch them. Especially, clothing fashion show ought to focus on beauty of clothes, do not let the beauty of models and stages covers over the beauty of clothes. Beside these, clothing tradesmen ought to focus on content of performance, communication with customers and mutual interaction, so that cause the willing of customers to purchase, share and recommend.

Third, clothing manufactures ought to strengthen the propaganda of clothes, keeping loyalty of customers, do not eagerly sell clothing products by reducing price for decreasing storage of clothes. Tradesmen should make clothing brand popular by way of clothing fashion show, let indentors and customers closely known and understood, obtaining the trust and goodwill of stakeholders.

\section{References}

[1] Arch G. Woodside,2012. Economic Psychology and Fashion Marketing
Theory: Appraising Veblen's Theory of Conspicuous Consumption, Journal of Global Fashion Marketing, Boston College University Libraries.

[2]Lise Skov, Else Skjold, Brian Moeran, Frederik Larsen and Fabian F. Csaba,2009. The Fashion Show as an Art Form, Creativity at Work, Creative Encounters Working Papers Series, www.cbs.dk/creativeencounters

[3] Michael Hutter \& Richard Shusterman, 2006. Value and the Valuation of Art in Economic and Aesthetic Theory. Handbook of the Economics of Arr and Culture. Volume1Edited by Victor A Ginsburgh and David Throsby. Elselvier B.V

[4]Moretta Tartaglione, Andrea and Antonucci, Emanuela, 2013.Value Creation Process in the Fast Fashion Industry: Towards a Networking Approach. Gummesson, E., Mele, C., Polese, F. (eds.), The 2013 Naples Forum on Service. Service Dominant Logic, Networks \& Systems Theory and Service Science: Integrating Three Perspectives for a New Service Agenda, p. 91.

[5]Wang Xinping\& Xu Shubo, 2015.0n Aesthetic Expression of Decorative Picture in Clothing Design. Journal of Package world,11,6,102103(Chinese ).

[6]Antony\& Aumann(2014).The Relationship Between Aesthetic Value and Cognitive Value. The Journal of Aesthetics and Art Criticism, Vol,72(2)

[7]J. P. Udo\& D. I. Fels (2010),Re-fashioning fashion: an exploratory study of a live audio-described fashion show. Universal Access in the Information Society Vol.9(1), pp.63-75.

[8]Jill Ross\& Rod Harradine(2010).Value brands cheap or trendy: An investigation into young consumers and supermarket clothing. Journal of Fashion Marketing and Management,Vol.14,(3)

[9]Marjan Michels\& WilMeeus\& Johan De Walsche (2016).Translation: Sentiment: The Basis for Developing Aesthetic Judgment. Asian Education Studies,7,Vol,1(1).

[10]Silberg\& Jon(2009).Lighting design: HD Production on bravo's fashion show. Pro Quest Journal,Vol.34(5), pp.10-11. 